\title{
PENINGKATAN KOMPETENSI PROFESIONAL GURU MELALUI PELATIHAN PENGGUNAAN MEDIA ICT
}

\author{
Ningrum Astriawati1), Gino Erman Agusta²), Himawan Aditya Pratama ${ }^{3)}$ \\ 1)Prodi Permesinan Kapal, Sekolah Tinggi Maritim Yogyakarta, Daerah Istimewa Yogyakarta, Indonesia \\ ${ }^{2}$ SMAIT Baitussalam, Sleman, Daerah Istimewa Yogyakarta, Indonesia \\ ${ }^{3)}$ Prodi Transportasi, Sekolah Tinggi Maritim Yogyakarta, Daerah Istimewa Yogyakarta, Indonesia \\ Corresponding author : Ningrum Astriawati \\ E-mail : astriamath@gmail.com
}

Diterima 23 Juni 2021, Direvisi 11 Juli 2021, Disetujui 12 Juli 2021

\begin{abstract}
ABSTRAK
Tujuan utama pengabdian kepada masyarakat (PKM) ini yaitu untuk meningkatkan kompetensi guru dalam mengelola kelas online melalui pelatihan penggunaan media information and communications technology (ICT) bagi guru-guru PAUD IT dan SD IT Harapan Bunda. Media ICT yang dipilih oleh guruguru PAUD IT dan SD IT Harapan Bunda adalah berbasis Google Forms dan Google Meet. Pelatihan dilakukan dengan pemberian materi, diskusi/tanya jawab, dan praktek langsung pembuatan media ICT yang digunakan. Untuk mengetahui keberhasilan kegiatan pengabdian ini, dilakukan evaluasi dengan pengisian angket respon terhadap kegiatan PKM, angket kepuasan serta angket kompetensi profesional guru. Dari hasil angket menunjukkan rata-rata persentase respon peserta pelatihan terhadap pelaksanaan PKM ini menjawab sangat setuju sebesar 70,7\%. Tingkat kepuasan peserta pelatihan dari segi materi, penyampaian materi, proses diskusi serta pelatihan individu adalah $93,3 \%$. Sedangkan sekitar $73,3 \%$ menyatakan mengalami peningkatan terkait kemampuan menggunakan media ICT dan pengelolaan kelas online. Dari hasil pelatihan juga disarankan agar guru-guru di masa pandemi ini lebih memahami dan menggunakan media ICT agar pembelajaran lebih efektif dan menyenangkan
\end{abstract}

Kata kunci: kompetensi; media ict; pelatihan; profesional

\section{ABSTRACT}

The main objective of community service is to increase teacher competence through training in the use of ICT media for PAUD IT and SD IT Harapan Bunda teachers. The ICT media chosen by PAUD IT and SD IT Harapan Bunda are based on Google Forms and Google Meet. The training was carried out by providing materials, discussion / question and answer, and direct practice of making the ICT media used. In addition to the introduction of ICT media, this training also conducted an assignment to better understand the use of online ICT media. Reliable in this service activity, evaluation is carried out by filling out questionnaires and direct interviews. The results of the questionnaire showed that the average proportion of training participants on the implementation of this community service answered strongly agree at $70,7 \%$. The level of satisfaction of the training participants in terms of material, material delivery, discussion process, individual training was $93,3 \%$. Meanwhile, around $73,3 \%$ stated that the increase was related to the ability to use ICT media and manage online learning. From the results of the training, it is also recommended that teachers during this pandemic better understand and use ICT media so that learning is more effective and fun.

Keywords: competence, media ict, training, professional

\section{PENDAHULUAN}

Peraturan Menteri Pendidikan Nasional Republik Indonesia (Permendiknas) Nomor 16 Tahun 2007 tentang standar kualifikasi akademik dan kompetensi guru menyebutkan bahwa guru TK/PAUD dan SD/ MI harus memiliki kompetensi untuk memanfaatkan teknologi informasi dan komunikasi (TIK) demi kepentingan penyelenggaraan kegiatan pembelajaran (Kemdikbud, 2007). Berdasarkan
Permendikbud tersebut sangat nyata tuntutan kompetensi profesional yang harus dimiliki guru terkait dengan pemanfaatan Information and Communication Technology (ICT). Kompetensi yang dimaksud adalah guru TK/PAUD dan SD / MI memiliki pengetahuan dan keterampilan memanfaatkan ICT untuk kepentingan pembelajaran. Hal ini didukung dengan Surat Edaran Nomor 4 Tahun 2020 Tentang Pelaksanaan Kebijakan Pendidikan Dalam 
Masa Darurat Penyebaran Corona Virus Disease (Covid-19) yang menekankan semua pembelajaran secara daring dari tingkat TK/PAUD sampai perguruan tinggi untuk menghindari penyebaran virus Corona (Kemdikbud, 2020).

Penggunaan ICT dalam proses pembelajaran, utamanya terlihat pada adanya perubahan seting pembelajaran, dari tatap muka (face-to-face) ke seting online melalui $e$ learning (Hassan, Rashida, 2011). Guru sebagai ahli isi pelajaran (subject matter expert), baik bekerja secara sendiri maupun berdampingan dengan tenaga pengembang teknologi pembelajaran, diharapkan dapat merancang, mengembangkan, dan memanfaatkan e-learning dalam pembelajaran (Wulandari, Hudallah, Rosyidi, 2016). Pengintegrasian ICT dalam pembelajaran memberikan berbagai kemudahan tidak hanya dalam bentuk perangkat keras (hardware) dan perangkat lunak (software) melainkan juga dalam bentuk sistem, strategi, metode dan teknik berkomunikasi (Sahid, 2007).

SD IT dan PAUD IT harapan bunda terletak di Kota Klaten secara aktif dan berkelanjutan mengembangkan kemampuan kompetensi profesional guru-guru dalam pengelolaan kelas online. SD dan PAUD IT merupakan sekolah-sekolah yang aktif mengirimkan para gurunya mengikuti pelatihan e-Learning baik mendatangkan ahli maupun ke tempat-tempat pelatihan. Berdasarkan observasi dan wawancara awal yang dilakukan dengan para guru dan kepala sekolah baik di PAUD maupun di SD IT diketahui bahwa para guru masih bingung dalam memanfaatkan media ICT untuk kegiatan belajar-mengajar maupun dalam evaluasi pembelajaran. Mereka hanya mengandalkan WhatsApp Group dan
Youtube selama proses belajar mengajar secara online.

Berdasarkan analisis situasi yang ada, dirasa sangat perlu meningkatkan pengetahuan dan keterampilan para guru PAUD dan SD IT dalam mengembangkan aktivitas pembelajaran online agar pembelajaran online lebih bervariasi. Hal ini mendorong pengembangan kemampuan guru untuk secara profesional memanfaatkan ICT dalam pembelajaran online. Dengan demikian, upaya meningkatkan kualitas pembelajaran untuk menghasilkan SDM yang berdaya saing tinggi untuk berpartisipasi dalam MEA akan berhasi ( Pangestika, Alfarisa, 2015).

\section{METODE}

Pelatihan pengelolaan kelas online bagi guru-guru PAUD IT dan SD IT Harapan Bunda di Kecamatan Manisrenggo, Kabupaten Klaten, diikuti sebanyak 15 peserta selama bulan Juli 2020. Metode yang digunakan dalam Pengabdian Kepada Masyarakat dalam rangka peningkatan kompetensi guru-guru adalah melalui pelatihan. Tahapan pertama yang dilakukan adalah dengan mendata jumlah guru yang berada di SD dan PAUD IT Harapan Bunda. Langkah selanjutnya adalah dengan melakukan analisis tentang tingkat pengetahuan dan kemampuan penggunaan media ICT bagi para guru yang mengajar. Setelah mengetahui tingkat pengetahuan dan kemampuan guru dengan memberikan pelatihan. Pelatihan dilakukan dengan pemberian materi, diskusi/ tanya jawab dan praktek langsung pembuatan media ICT yang digunakan, seperti yang terlihat pada Gambar 1 berikut.

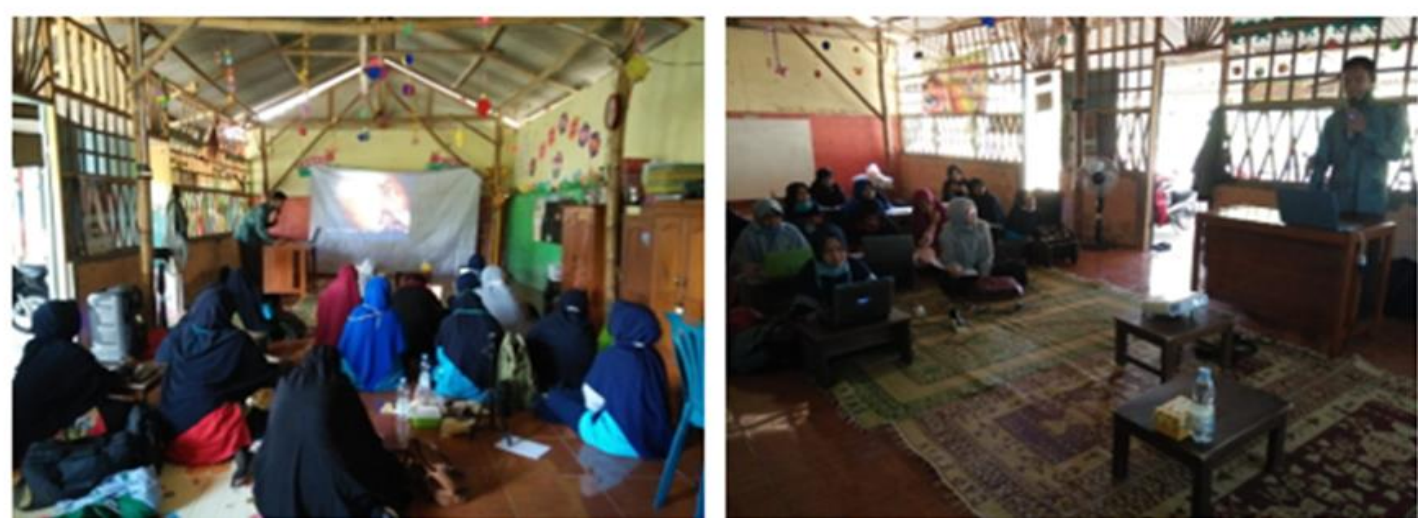

Gambar 1. Tim pengabdi sedang memberikan materi

Dalam pelatihan yang dilaksanakan tim pengabdi, peserta, dan mitra sekolah selalu bersifat kooperatif dalam penyediaan ruang untuk pelatihan dan fasilitas wifi sekolah. Setelah selesai semua pelatihan tim yang bergabung dalam PKM tetap melakukan koordinasi dengan Tim mitra sekolah untuk selalu melakukan pemantauan penggunaan media ICT yang dipilih. Di akhir kegiatan PKM dilaksanakan evaluasi terhadap kegiatan yang 
dilakukan. Pelaksanan evaluasi menggunakan angket respon terhadap pelaksanaan PKM. Angket ini diisi oleh guru-guru peserta pelatihan. Angket respon ini terdiri atas 5 bagian utama yaitu tentang (1) isi pokok materi yang disampaikan oleh tim pengabdi, (2) penyampaian materi tim pengabdi, (3) tanya jawab atau diskusi tim pengabdi dengan peserta pelatihan, dan (4) praktik/pelatihan individu dalam penggunaan media ICT dan (5) Hasil pelatihan penggunaan media ICT. Setiap pertanyaan terdapat 5 pilihan jawaban yang harus dipilih oleh peserta pelatihan, diantaranya: jawaban sangat setuju, setuju, netral, tidak setuju, sangat tidak setuju. Berdasarkan hasil evaluasi tersebut, para peserta diberikan berbagai penguatan untuk meningkatkan pemahaman secara lebih lanjut tentang efektivitas pemanfaatan media online dalam melangsungkan kegiatan belajar mengajar secara online. Program pengabdian ini akan dikatakan berhasil apabila respon sangat setuju peserta pelatihan terhadap kegiatan ini lebih besar dari $70 \%$, dan tingkat kepuasan serta peningkatan kompetensi guru lebih besar dari $70 \%$.

\section{HASIL DAN PEMBAHASAN}

Tim pengabdian memulai kegiatan dengan menghubungi dua Kepala Sekolah SD IT dan Kepala Sekolah Paud IT Harapan Bunda. Kepala Sekolah sangat antusias dan menyambut baik kegiatan PKM yang dilaksanakan di sekolahnya. Kepala Sekolah sedapat mungkin untuk mengusahakan agar semua guru berpartisipasi aktif dan terlibat dalam kegiatan PKM ini. Tim PKM terdiri atas 2 dosen dan 1 guru dengan bidang ilmu yang berbeda, yaitu bidang Matematika, Manajemen dan Pendidikan. Langkah pertama yang dilakukan oleh tim PKM adalah mengunjungi lokasi tim mitra yang menjadi sasaran PKM dan mendiskusikan rangkaian jadwal yang akan dilaksanakan selama proses kegiatan pengabdian berlangsung dengan Kepala Sekolah SD IT dan Kepala Sekolah PAUD IT Harapan Bunda. Langkah selanjutnya yang dilakukan oleh tim adalah dengan melakukan pendataan terkait kompetensi dan kemampuan penggunaan komputer dan penggunaan HP bagi guru-guru yang mengajar di sekolah tersebut.

Pendataan ini dilakukan dengan memberikan angket tentang pengetahuan mengenai berbagai macam media ICT dan memilih media ICT yang akan digunakan sebagai penekanan pelatihan. Berikut data yang diperoleh setelah disebarkan angket:



Gambar 2. Persentase pengetahuan dan pemilihan media ICT

Dari Gambar 2 diatas diperoleh bahwa pengetahuan tentang media ICT yang digunakan untuk media belajar mengajar secara online yang paling tinggi adalah pengetahuan menggunakan WhatsApp Group (WAG) sebesar $100 \%$, dengan kata lain peserta pelatihan selama pembelajaran online semuanya telah menggunakan WAG. Pengetahuan tentang media ICT kedua adalah Google Forms sebesar $66,67 \%$ disusul dengan Youtube sebesar 53,33\%. Sedangkan pengetahuan yang paling rendah adalah tentang aplikasi Webex yaitu $0,00 \%$, dengan kata lain tidak ada peserta pelatihan yang mengetahui aplikasi tersebut. Pengetahuan tentang Zoom sebesar 13,33\%, pengetahuan tentang Google Classroom sebesar 46,67\%, Google Meeting sebesar 20,00\%, Moodle sebesar 13,33\%, Edmodo sebesar 6,67\%, dan pengetahuan tentang Skype sebesar $13,33 \%$.

Pemilihan pelatihan media ICT tertinggi adalah Google Forms yaitu $100 \%$, artinya bahwa semua peserta memilih untuk mengetahui lebih dalam terkait penggunaan 
Google Forms, pemilihan tertinggi kedua adalah Google Meet yaitu sebesar 86,67\%. Sedangkan aplikasi lainnya kurang dari $50 \%$, yaitu untuk Youtube sebesar 40\%, Zoom sebesar 26,67\%, Google Classroom sebesar 20,00\%, Moodle dan Edmodo sebesar 6,67\%, sedangkan untuk WAG dan Skype sebesar $0 \%$, yang artinya peserta pelatihan tidak memilih untuk pelatihan tersebut. Setelah memperoleh data tersebut, tim pengabdian membuat rapat lanjutan untuk menyusun materi pengabdian masyarakat yang dilaksanakan di Paud dan SD IT Harapan Bunda, materi pengabdian disesuaikan dengan pemilihan media ICT para peserta pengabdian yaitu terkait dengan penggunaan Google Forms dan Google Meeting dalam proses belajar mengajar.

Selanjutnya tim pengabdian menemui Kepala Sekolah SD IT dan Kepala Sekolah TK IT Harapan Bunda untuk dapat menentukan jadwal pelatihan dan pembimbingan dalam penggunaan media ICT yang dipilih oleh peserta pelatihan. Peserta pelatihan sangat antusias sekali dalam mengikuti pelatihan, hal ini dikarenakan peserta pelatihan merupakan guruguru PAUD dan SD IT yang masih sangat jarang menggunakan media ICT. Dalam sesi pelatihan berlangsung selain mempresentasikan materi yang dipilih, juga terdapat sesi tanya jawab dan praktik/ pelatihan secara individu Dari hasil pelatihan individu terlihat bahwa peserta pelatihan dapat membuat soal-soal untuk siswa-siswa yang ingin diajarkan secara online. Peserta pelatihan dapat memasukkan gambar dan video, selain itu peserta pelatihan juga dapat memasukkan Bahasa asing, dalam hal ini Bahasa Arab kedalam pembuatan Google Forms. Untuk dapat mengetahui respon terhadap kegiatan pelaksanaan PKM ini, tim pengabdi memberikan angket setelah pelaksanaan PKM dilakukan. Hasil kuesionernya terlihat pada grafik berikut:

\section{RESPON KEGIATAN PENGABDIAN}

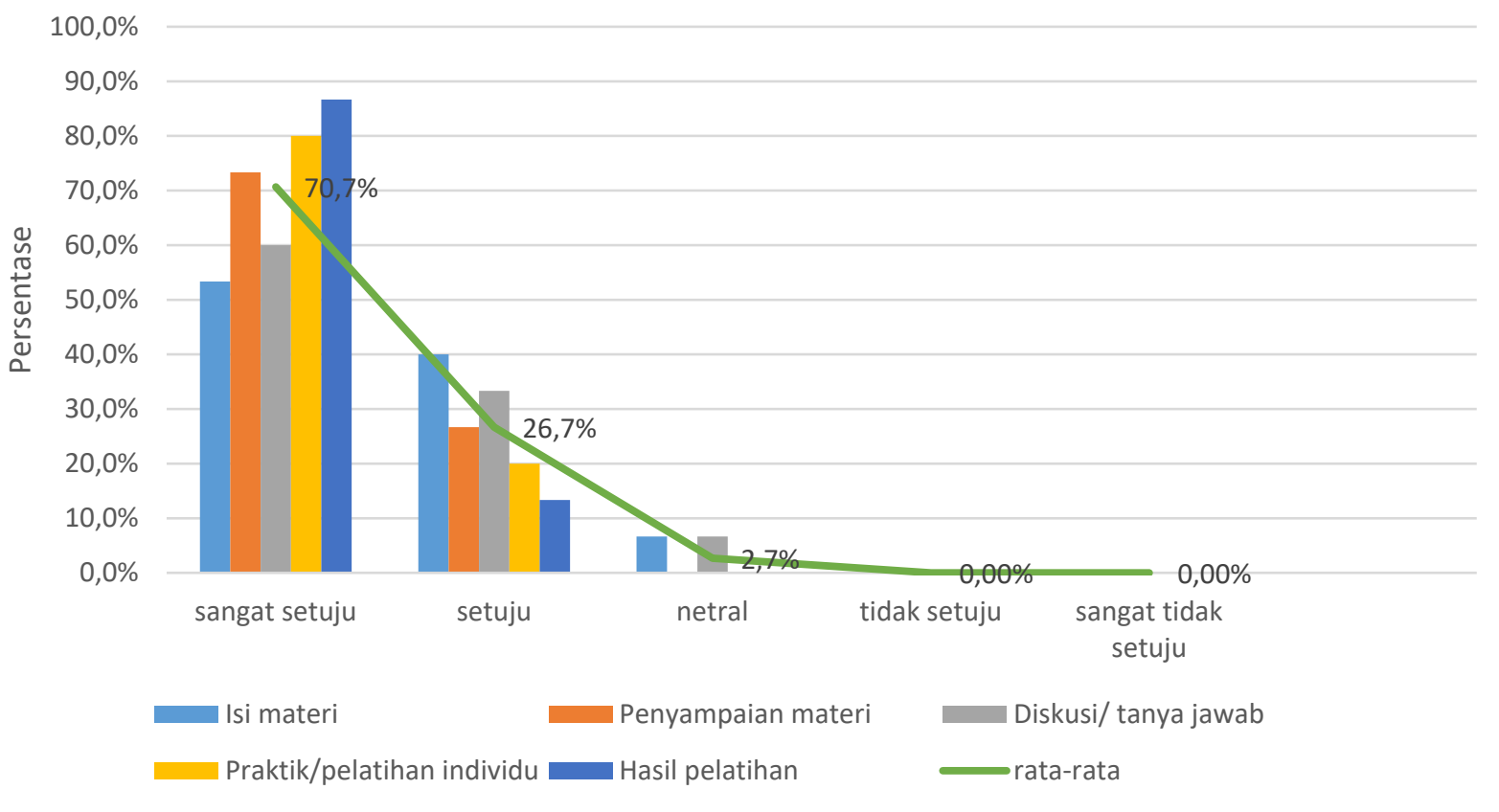

Gambar 3. Respon peserta pelatihan terhadap hasil pengabdian 
Dari Gambar 3 dapat dijabarkan bahwa rata-rata peserta pelatihan sangat setuju dengan pelatihan yang diadakan baik dari sisi materi, penyampaian materi, diskusi/ tanya jawab dan praktik/ Pelatihan individu. Untuk kejelasan isi materi yang disampaikan tim pengabdi mendapatkan jawaban sangat setuju sebesar 53,3\%, setuju sebesar $40 \%$ dan menjawab netral sebesar 6,7\%. Untuk kejelasan penyampaian materi yang dipresentasikan tim pengabdi mendapatkan jawaban sangat setuju sebesar $73,3 \%$ dan setuju sebesar $26,7 \%$. Untuk ketepatan waktu diskusi dan sesi tanya jawab yang disampaikan tim pengabdi mendapatkan jawaban sangat setuju sebesar $60 \%$, setuju sebesar $33,3 \%$ dan menjawab netral sebesar 6,7\%. Sedangkan untuk ketepatan pelaksanaan praktik/pelatihan individu mendapatkan jawaban sangat setuju sebesar $80 \%$ dan setuju sebesar $20 \%$. Sedangkan untuk Hasil pelatihan dalam menunjang kompetensi guru mendapat jawaban sangat setuju sebesar $86,7 \%$ dan setuju sebesar $13.3 \%$. Dari lima pertanyaan yang disampaikan ke peserta pelatihan jawaban sangat setuju paling tinggi diperoleh pertanyaan terkait Hasil pelatihan dalam menunjang kompetensi guru. Hal ini terlihat dari antusiasme peserta pelatihan dalam mengikuti semua rangkaian kegiatan pengabdian ini. Sedangkan rata-rata respon peserta pelatihan terhadap pelaksanaan pengabdian ini adalah menjawab sangat setuju sebesar $70,7 \%$, menjawab setuju sebesar $26,7 \%$ dan menjawab netral sebesar $2,7 \%$. Hal ini menunjukkan bahwa PKM yang dilaksanakan di SD IT dan PAUD IT Harapan Bunda mendapatkan respon positif dari peserta pelatihan.

Selain angket respon terhadap kegiatan PKM, juga disebarkan angket tentang kepuasan terhadap kegiatan PKM yang dilaksanakan dan kompetensi profesional guru, sekitar 93,3\% (14 dari 15 peserta pelatihan) menyatakan puas terhadap kegiatan PKM ini, dan sekitar $73,3 \%$ ( 11 dari 15 peserta pelatihan) menyatakan mengalami peningkatan terkait dengan kemampuan menggunakan media ICT dan mengelola pembelajaran secara online. Dari hasil wawancara juga menyatakan PKM yang dilaksanakan menambah pengetahuan dan keterampilan peserta pelatihan terhadap pengelolaan kelas online. Sehingga program pengabdian ini dikatakan berhasil.

Peningkatan profesional guru di masa pandemi Covid-19 yang merubah sistem pembelajaran dari face to face ke sistem online memang harus diupayakan dan ditingkatkan. Dipilihnya pelatihan tentang model-model pembelajaran inovatif seperti pemilihan media
ICT yang digunakan oleh guru merupakan salah satu upaya untuk meningkatkan kompetensi guru dalam mengajar dimana muaranya nanti adalah pada peningkatan pemahaman siswa sebagai akibat dari proses pembelajaran yang aktif, inovatif, kreatif, efektif, menyenangkan dan berbobot (Sumaryati,, 2013).

\section{SIMPULAN DAN SARAN}

Kegiatan Pengabdian Kepada Masyarakat (PKM) berupa pelatihan penggunaan media ICT bagi guru-guru PAUD IT dan SD IT di Kecamatan Manisrenggo, Kabupaten Klaten, diikuti sebanyak 15 peserta selama bulan Juli 2020. Pelatihan dilakukan dengan pemberian materi, diskusi/ tanya jawab dan praktek langsung pembuatan media ICT yang digunakan. Dari hasil pelatihan menunjukkan respon positif semua peserta pelatihan. Persentase rata-rata respon peserta pelatihan terhadap pelaksanaan pengabdian ini menjawab sangat setuju sebesar $707 \%$. Tingkat kepuasan peserta pelatihan yang diperoleh adalah $93,3 \%$, yang artinya bahwa 14 dari 15 peserta pelatihan menyatakan puas dengan bentuk kegiatan PKM ini. Sekitar 73,3\% menyatakan mengalami peningkatan terkait dengan kemampuan menggunakan media ICT dan mengelola pembelajaran secara online. Dari hasil pelatihan juga disarankan agar guruguru di masa pandemi ini lebih memahami dan menggunakan media ICT agar pembelajaran lebih efektif dan menyenangkan.

\section{UCAPAN TERIMA KASIH}

Pengabdian Kepada Masyarakat ini didanai oleh Lembaga Penelitian dan Pengabdian kepada Masyarakat Yogyakarta Sekolah Tinggi Maritim. Kami berterima kasih kepada kepala sekolah PAUD IT dan kepala sekolah SD IT Harapan bunda, serta guru-guru mata pelajaran yang telah berpartisipasi aktif demi suksesnya PKM ini.

\section{DAFTAR RUJUKAN}

Kemdikbud, (2020) "SURAT EDARAN MENDIKBUD NO 4 TAHUN 2020 TENTANG PELAKSANAAN KEBIJAKAN PENDIDIKAN DALAM MASA DARURAT PENYEBARAN CORONA VIRUS DISEASE (COVID- 1 9) - Pusdiklat Pegawai Kementerian Pendidikan dan Kebudayaan," Https://pusdiklat.kemdikbud.go.id/,...

J. Hassan and F. Rashida, (2011). "Penggunaan ICT Dalam Proses Pengajaran Dan Pembelajaran Di Kalangan Pendidik Fakulti Pendidikan Universiti Teknologi Malaysia Skudai, 
Johor," J. Tech. Vocat. Eng. Educ.

K. A. Wulandari, N. Hudallah, and I. Rosyidi, (2016). "PERAN GURU TEKNOLOGI INFORMASI DAN KOMUNIKASI TERHADAP KOLEGA SEJAWAT DALAM PROSES BELAJAR MENGAJAR Prodi PTIK FT Unnes 2 SMP Negeri 2 Kendal," J. Penelit. Pendidik. Indones.

Kemdikbud, (2007). "Peraturan Menteri Pendidikan Nasional Nomor 16 Tahun 2007," vervalsp.data.kemdikbud.go.id.

R. R. Pangestika and F. Alfarisa, (2015). "Pendidikan Profesi Guru (PPG): Strategi Pengembangan Profesionalitas Guru dan Peningkatan Mutu Pendidikan Indonesia," Pendidikan Profesi Guru.

Sahid, (2007). "Pengembangan Media Pembelajaran Berbasis ICT," Pendidik. Mat. FMIPA UNY.

S. Sumaryati, (2013). "Peningkatan kompetensi profesional guru melalui pelatihan model-model pembelajaran inovatif," INOTEKS, vol. 17, no. 2. 